\title{
VSTUP DO PROJEKTOVANIA PRÍPRAVY MULTIMEDIÁLNYCH PROGRAMOV V EDUKAČNOM PROCESE
}

\begin{abstract}
Ján STEBILA
(PIECUCH, A. Wstęp do projektowania multimedialnych opracowań metodycznych. 1. vyd. Rzeszów:
\end{abstract} Wydawnictwo Oświatowe Fosze, 2008. 397 s. ISBN 978-83-88845-97-0)

Predkladaná a predmetná štúdia je d’alšou z radu návodov a inštruktáži, v ktorej si dáva autor za ciel' uviest' čitatel'a do problematiky prípravy, projektovania a tvorby MDP. Tento ciel' má byt' naplnený v celom obsahu štúdie.

Obsah je rozdelený do šiestich kapitol. Prvá kapitola Praktické podklady pre návrh MDP (Zaloźenia do projektowania multimedialnych programów dydaktycznych) opisuje proces spojený s komunikáciou medzi človekom a počítačom. Taktiež sa zaoberá nevyhnutnost’ou plánovania pokusov spojených s realizáciou multimediálnych programov. Druhá kapitola Metodológia navrhovania MDP (Metodyka konstruowania multimedialnych programów dydaktycznych) čelí teoretickým aspektom navrhovania multimédií. Edukačný proces charakterizuje špecifickú konštrukciu, ktorá je odlišná, ako napr. typicky prospešný program. Toto dovol'uje príjemcovi použit' tú formu, ktorá je optimálna pre jeho individuálne predispozície. Použivatel'ské rozhranie (Interfejs programowy uźytkownika) je názov tretej kapitoly. Funkčnost' programu závisí od jeho dôkladnej a náročnej konštrukcie. V nasledujúcich podkapitolách sa diskutuje o komponentoch užívatel'ského rozhrania: menu, dialóg medzi uživatel'om, správy pre užívatel'a, interpretácia a jazyk komunikácie. Sumárom tejto kapitoly je podat' podrobnosti $\mathrm{k}$ viac všeobecným princípom zaoberajúcim sa návrhom užívatel'ského rozhrania. Najrozsiahlejšia je štvrtá kapitola Komponenty MDP (Komponenty multimediatnych opracowań metodycznych), ktorá sa sústred’uje na návrh a realizáciu MDP.
Obsah tejto kapitoly tvoria záležitosti týkajúce sa modelovania štruktúry hypertextu, počítačová grafika, animácia počítačovej simulácie, zvukové a didaktické filmy a obrazová kompozícia. $\mathrm{Na}$ malom priestore je spomenutá aj fyzická a psychická ergonomia užívatel'a MPD. Piata kapitola Kritéria vyhodnocovania MDP (Kryteria oceny multimedialnych programów dydaktycznych) sa sústred'uje na problémy overovania

didaktického softvéru. Špeciálna pozornost' bola venovaná užívatel'om programu a na široké spektrum problematiky zaoberajúcej sa MDP vyhodnocovaním.

Posledná kapitola $M D P$ vškolskej praxi (Multimedialne

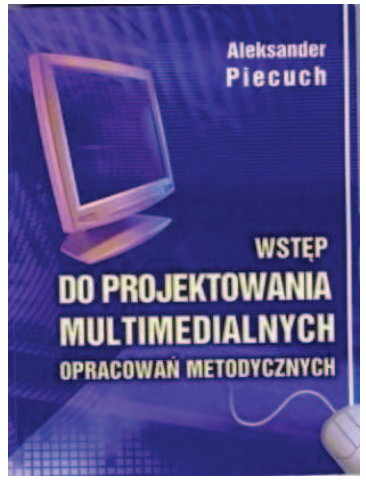
programy dydaktyczne $w$ praktyce szkolnej) diskutuje o problémoch s používaním niektorých multimediálnych zariadení v škole. Je venovaná používaniu encyklopédií, knihám, multimediálnym cvičeniam a pol'ským edukačným portálom.

Záverom možno konštatovat', že kompletný text štúdie preukazuje kvalitné rozpracovanie danej problematiky. Zároveň podporuje oblast' teoretických poznatkov s praktickými výstupmi. Štúdia má všetky predpoklady stat' sa dobrým zdrojom informácií $\mathrm{v}$ tejto problematike nielen $\mathrm{v}$ Pol'skej republike, ale aj v zahraničí. 